\title{
Inclusive Growth Effects of Institutional Quality in Nigeria
}

\section{Gideon O. Olanrewaju, PhD}

Department of Economics, Babcock University, Ilishan-Remo, Ogun State, Nigeria

\section{Adeleke Gabriel Aremo, PhD}

Department of Economics,

Obafemi Awolowo University, Ile-Ife, Osun State, Nigeria

\section{Babatunde O. Binuyo,}

Department of Economics,

Babcock University, Ilishan-Remo, Ogun State, Nigeria

\begin{abstract}
This study empirically examined the relationships between institutional quality and inclusive growth as measured by the real GDP per person employed (RGDPE) in Nigeria. An Autoregressive Distributed Lag (ARDL) Bounds testing approach to cointegration was employed using annual secondary time series data from 1998 to 2017. The data were sourced from the Central Bank of Nigeria's statistical Bulletin, National Bureau of Statistics' final Accounts, IMF's International Financial Statistics (IFS) and Worldwide Governance Indicators (WGIs). The study concluded that institutional quality had a significant effect on inclusive growth in Nigeria. It is therefore recommended that institutional improvement beyond the present liberal democratic threshold is much needed to effectively harness the human capital resource base. The Nigerian government should adopt a labour-intensive development strategy such that poor active households are comprehensively integrated into productive activities for optimal value-chain finance-growth inclusiveness. This would address the protracted tripartite socio-economic problems of poverty, inequality and unemployment in line with Lin's comparative advantage conforming hypothesis. e. This would enhance formulating and implementing employment growth-oriented policies that are compatible with the society's resources endowment and developmental goals.
\end{abstract}

Keywords: Institutional quality, Development strategy, Broad-based growth, Employment 


\section{Introduction}

Many speculate that the development differentials between the advanced countries and that of most low-income developing economies are due to differences in the institutional factors that affect the rates of economic growth and inclusiveness. However, contextualizing the critical role plays by institutions of governance in fostering a broad-based productive employment growth remains one of the most challenging puzzles to have emerged in the resource-rich developing countries like Nigeria. While the growing body of empirical research has established the links between institutions and differential growth paths across countries, country-specific studies that have explored the dynamism of inclusive growth as a triple-win solution to the tripartite socio-economic problems of poverty, inequality and unemployment are not only sparse, but there seem actually no consensus explanation yet on whether institutional quality is more of a cause variable rather than consequence. Moreover, the few available studies have not been able to acknowledge the impossibility of 'an inherently exclusive market' as the best inclusive growth strategy for the low-middle income developing economies like Nigeria.

Over time, the historical perspectives of the old industrialized economies like the United States and Europe; and also the fascinating results from study on the Newly Industrialized Economies (NIEs) in Asia and the BRICS' countries have shown that their seemingly equitable economic growths did not follow the conventional neo-classical growth theories in their strict tenets (Martinez \& Mlachila 2013; Jerome, 2016). Thus, almost all the countries that were regarded the most successful in making growth largely more inclusive had such a strategic and transformative effects of the state institutional quality in their economies. As a result, these countries have been widely acknowledged to have consistently pulled millions of their people out of poverty, sizably reduced inequality gaps and lowered the unemployment rates through a purposeful institutional capacity and character of the state (Ghatak, 2003; Peet \& Elaine (2009).

Notably, in contrast, the Nigerian economy has continued to be daunted by somewhat inexplicable paradoxes. For example, the country though immensely so blessed, yet always ranked as one of the countries with the worst poverty incidence. Being the sixth largest producer of crude oil, still imports finished petroleum products over the years. Has more places of worship per square meter than the most nations on earth, yet corruption and violence have continued to threatening our corporate existence. Having lived together as a nation for over one hundred years, still yet daily you hear stories of her breaking up. Most surprisingly, during the last one-and-half decades preceding the recent recession, Nigeria remarkably had witnessed an impressive average growth rate of about 7.0 per cent, yet the growth was 
substantially non-inclusive. Despite the rebasing of her GDP in 2013 in which the country emerged as the largest and fastest growing economy in Africa and $26^{\text {th }}$ in the whole world, the attainment of this growth episode did not translate into significant improvements in the socio-economic life of average citizens (reductions in unemployment rate, poverty, and income/wealth inequality). Unfortunately, the reverse has been the case (Ozughalu \& Ogwumike, 2015).

To this end, focusing on a broad-based active participation and not just on distribution outcomes in the growth narratives for the low-income developing countries in order to 'catch up' can no longer be over-emphasized. The 'growth-first' notions and hoping that these outcomes will trickle down to developmental outcomes are no longer adequate and equally out of touch with the present realities, particularly for the resource-rich and labourabundant developing economies like Nigeria. As noted by Chang, 2011), the route to inclusive growth lies in shifting to investment in human capital and innovations for productive economic activities (structural transformation). This is because, without a broad-based socio-economic transformation, the ravaging tripartite socio-economic problems of poverty, inequality and unemployment will continue to be increasingly unassailable in these lowincome developing countries like Nigeria (Stiglitz, 2016).

Traditionally, given the state's apparent resilience in terms of capacity and character, it has always become the only viable agent that has a vested interest in ensuring a growth with inclusiveness by creating equitable economic opportunities along with equal access to them by all, particularly by those hitherto excluded (the poor and the vulnerable in society) from the growth process. Thus, the mounting tripartite socio-economic problems of pervasive poverty, huge inequality gap and worrisome unemployment rate, now manifesting in their diversely variegated socio-upheaval dimensions (insurgency/militancy, kidnapping, terrorism, vandalism, and the like), which are attributable to social and financial exclusions could be reversed.

Against this backdrop, it is therefore not hard at all for anyone to imagine the critical missing links in the inclusive growth process. With the unbroken democratic rule in Nigeria since 1999, it is imperative to see how the 'improved' political governance has helped in fostering, or otherwise, financial development and inclusive growth in the country. This study therefore, is guided by the work done on the financial inclusion-growth link, and the belief that the quality of institutions underlies the causal interactions between financial inclusion and inclusive growth. Employing the ARDL Bounds testing framework, this study investigated the short-run and long-run effects of institutional quality on the real GDP per person employed in Nigeria while controlling for indicators of technology choice and financial inclusion. Hence, the study assessed the effect of institutional quality on inclusive growth 
which is measured by the real GDP per person employed variable in Nigeria between the periods of 1998 and 2017.

In order to examine the institutional role of the state within the analytical governance framework (GAF), the study's variables of interest are the standardized worldwide composite governance indicators of institutional quality (GEFe) due to Kaufumann, Kraay and Mastruzzi (2010), the constructed index of financial inclusion (IFI) to measure financial inclusion's three dimensions of availability, accessibility and usage of formal financial services (Sarma, 2008), and real GDP per person employed (RGDPE) as proxy for inclusive growth. Other aggregate proxy indicators include technology choice index (TCI) constructed as the value-added to labour ratio in manufacturing over the total value-added to aggregate labour force ratio (Bruno, Douarin, Korosteleva and Radosevic (2015). The paper is structured as follows: Section 2 presents the review of literature on relationship between inclusive growth and institutional quality. Section 3 describes the data and methodology. Section 4 presents and discusses the empirical results while Section 5 concludes.

\section{Literature Review}

Building on the earlier intuition by North (1981), the field of development economics has come to recognize the institutional imperative of growth inclusiveness. However, two main divergent views on the crucial role of institutional quality in enhancing growth process through financial enablement and empowerment of society at large have undoubtedly continued to motivate a sizeable body of scholarship. On the one ground, several authors (La Portal, 1998; Chang, 2011; Acemoglu \& Robinson, 2013; Onwusu \& Odhambo, 2014; Kebede \& Takyi, 2017) stress that political institution is endogenous to a country's financial development and growth, and this considerably accounts for growth variance both across countries, and over time, within countries.

On the other hand, scholars (Sachs, 2005; Durlauf et al. 2005; Kurtz \& Schrank, 2007; Rodrik, 2008; Anders \& Tamayo, 2015; Briguglio, 2016) among others, hold different theoretical perspective on the link between institutional quality and growth. They dismiss governance out of hand, and assert that poor countries cannot afford quality institutions of governance. Moreover, the existence of causality between institutional quality and growth is less certain, and rather could as well run the other way round. Thus, their perceived negative correlation between governance and growth seems to contradict a commonly held view that development and institutional quality generally go hand-in-hand.

La Porta, et al., (1998) commence a research line on the quality of governments on various outcomes in 152 countries using government 
performance measures such as public sector efficiency, public good provision, size of government, and political freedom. The study found that countries that are poor, use French or socialist laws, or have high proportions of Catholics or Muslims exhibit inferior government performance. Moreover, the author consistently maintains that the larger governments tend to be the better in their performance and vice versa. In addition, the importance of historical factors such as, the economic, political, and cultural theories of institutions, explain the variations in government performance across countries.

Ajayi (2002) examines the theory and facts of how the quality of institutions and policies applied to the African situation. He observed that the missing link in Africa's growth process is the absence of adequate policies and efficient institutions. He found that corruption; ethno-linguistic fractionalization and civil strife as the institutional quality measures which have deleterious effects on growth. He also found that the conventional economic factors responsible for growth in Africa generally, and Nigeria in particular, do not fully explain its growth process. The study is relevant to the present as it has created useful insight into the problem which the present study sets out to solve.

Consistent with Ajayi's advocacy, Sachs (2005) describes the less developed countries (LDCs) as being caught in a structural poverty trap which he attributed to untapped productive forces compounded by asymmetric globalization. However, he contends that in spite of the odds, these countries still have a latent potential for evolving growth inclusiveness and sustainable development strategies, capable of breaking the vicious circle of underdevelopment and poverty within the framework of democratic developmental states. He strongly opines that 'development from within is the best, if not the unique opportunity; and that genuine development of Africa cannot happen by replicating foreign models. Thus, this study has further provided the desired stimulus for the present study. Policy implication of findings to government is that a 'home grown' inclusive framework should be evolved for triple-win solutions to the tripartite socio-economic concerns.

Furthermore, Lin (2009) highlights the links among factor endowments, institutions and differential growth paths testing the effects of both the CAC and CAD strategies on economic performance, on a sample of 122 countries in the period from 1962 to 1999. As a proxy variable for CAD, the author employed the relative size of capital-intensive production and also included a variety of institutional control variables (index of economic freedom, the costs of starting a business, ratio of trade dependence etc.). The findings indicate that the CAD strategy indeed has a statistically significant negative effect on growth and leads to an increase in inequality. The author argues that the government that adopts a CAD strategy encourages firms to ignore the existing comparative advantages of the economy in their entry of 
industry and this largely would be responsible for giving firms subsidies in order to compensate for losses arising from policy burdens. Consequently, the economy would be unproductive and full of rent-seeking.

Taking a closer look at two critical issues of governance and institutional quality measurement and direction of causality between institutional development and economic development in the developing Asian countries, Zhuang, de Dios and Lagman-Marrtin (2010) examine the role of governance and institutions. Applying a simple classification framework under the widely used world governance indicators (WGIs), the authors found that the Asian economies with government effectiveness, regulatory quality, and rule of law scored above the global means and grew faster on average during the period 1998-2008, than those economies below the global means. In effect, their findings are consistent with Levy and Fukuyama (2010) that, improving governance in these three dimensions could be used as potential entry points of development strategies for many other developing economies in the region and elsewhere.

In their recent study, Acemoglu and Robinson (2013) provide a quick overview of the literature on how institutions matter for development, and such the success or failure of any nation is largely contingent upon its political institution, and not the economic institutions, geography, culture or value systems. The authors, thus, view a country's political institution as the main determinant of other economic institutions, which in turn determines the country's ultimate success or failure. The study argues that countries with "extractive" political systems — in which power is wielded by small elites either fail to grow broadly or wither away after short bursts of economic expansion. In their opinion, more specifically, economic growth depends on widespread technological innovation and that only could be sustained by intellectual property environment underpinned by political equality for a shared-economic prosperity.

Saez (2013) provides a review essay on the strengths and weaknesses of different methodological approaches to the study of the relationship between governance and inclusive growth. Randomized Controlled Trials (RCTs) is one of the preferred approaches that appear to offer the most optimal 'bridging' link between variable-based and qualitative approaches. The author observed that in spite of the fact that a lot of seminal and cutting-edge works have been done on the link between governance and economic growth, there is no yet a comprehensive time-series using inclusive growth indicators. While the econometric analyses tend to view good governance as a precondition for optimal financial development, the qualitative case-studies tend to view good governance as a precondition to support inclusive growth policies. Thus, it was inferred that neither approach seriously engages with governance as a central determinant of inclusive growth. Exploring therefore, datasets that would 
enable the development of more testable hypotheses on the link between governance and inclusive growth remains imperative and therefore the focus of this present study.

Assessing the role of institutions on economic growth for a panel of 35 Asian countries over the period 1996 to 2012, Nawaz, Iqbal and Khan (2014) employ the fixed effects and System-Generalized Method of Moments (SYSGMM) estimation technique. The study constructs institutional quality index using six worldwide governance indicators. Theoretically, as institutional quality improves, the rent-seeking activities decrease and hence income increases and vice versa. The empirical findings though supportive of the hypothesis that institutions exert positive impact on the long-run economic growth, they maintain that it is relatively more effective in the developed Asia than in the developing Asian countries. Thus, the impact of institutions on economic growth could vary widely across economies depending on the level of economic development. Implying that, different countries require different set of institutions to promote inclusive growth and development.

Similar to the Lin (2009)'s study of country's relative comparative advantage, Siddique (2016) also examines the effects of adopting a Comparative Advantage-Defying (CAD) as opposed to Comparative Advantage Conforming (CAC) development strategy using data for the period of 1963 to 1999 and 1980 to 2000 for 113 countries. The author equally assesses how CAD strategy differs with the levels of financial development and its effect on poverty in their various economies. The findings show that the more aggressively a country adopts CAD development strategy, the higher the level of poverty incidence. However, a high level of financial development was found to reduce poverty-increasing impact of adopting CAD. Thus, adopting a Comparative Advantage-Conforming (CAC) development strategy, rather facilitates a country's entry into an industrial growth and thereby leading significantly to reduction in poverty and inequalities in most resource-rich and labour-abundant developing countries.

Ayinde and Yinusa (2016) employ the quantile regression technique to investigate the relationship between financial development and inclusive growth in Nigeria for the period 1980-2013. The findings show that the impact of financial development on inclusive growth depends on the measure of the former up to the threshold level of 90th percentile and not beyond; and the direction of causality between financial development and inclusive growth was reversed. Moreover, financial inclusion rather than financial deepening was equally found to positively impact on inclusive growth. However, the study observes that the government intervention poses a detrimental effect on private financial development activities during the period.

A more recent study by Kebede and Takyi (2017) on whether institutional quality is the consequence or cause of economic growth in 27 
Sub-Sahara African countries, using the Wald panel causality and the system GMM techniques, the co-integration test results show evidence of a long-run relationship between institutional quality and economic growth. The finding also revealed a one-way causality from economic growth to institutional quality and with no evidence of feedback. However, debt servicing and dependence on natural resources were respectively found to be negatively affecting economic growth and institutional quality. This conclusion suggests the case of resource cursed situations as being the lots of low- and low middleincome developing countries like Nigeria. Nevertheless, assuming that Kebede and Takyi (2017), Ayinde and Yinusa (2016), Nawaz, et al. (2014) among others, have included control variables such as interaction of institutional quality with both real GDP per person employed and financial inclusion, as well preferred development strategy indicator (technology choice index-TCI) in the estimated models, probably a more robust outcome would have resulted.

Against this backdrop, the present study was therefore deemed apt to investigate how the 'improved' political governance and the supposedly financial sector liberalizations for 'inclusion' in Nigeria has helped to foster inclusive growth; or else, what needs to be done to achieve the "new growth path' in the economy. The study therefore, was guided by the work done on the financial inclusion-growth link, and the belief that the quality of institutions underlies the causal interactions between financial inclusion and inclusive growth. The study empirically investigates finance-inclusive growth nexus within the governance analytical framework (GAF). Notably, there seems to be no study that has considered the combined effects of real GDP per person employed, financial inclusion and institutional quality which could condition growth inclusiveness in Nigeria. Filling this potential gap, the present study objectively amines the impact of institutional quality on inclusive growth in Nigeria employing the ARDL bounds test approach.

\section{Model Specification}

However, Governance Analytical Framework (GAF) stands out in identifying the way in which the quality of institutions through a broad-based financial inclusion influences inclusive growth (dependent Most importantly, this study explores how 'the new growth path' constitutes the triple-win solution the tripartite socio-economic problems of poverty, inequalities and unemployment discussed earlier particularly as it relates to what is now understood as inclusive growth in the resource-rich and labour-abundant lowincome developing economies like Nigeria. 


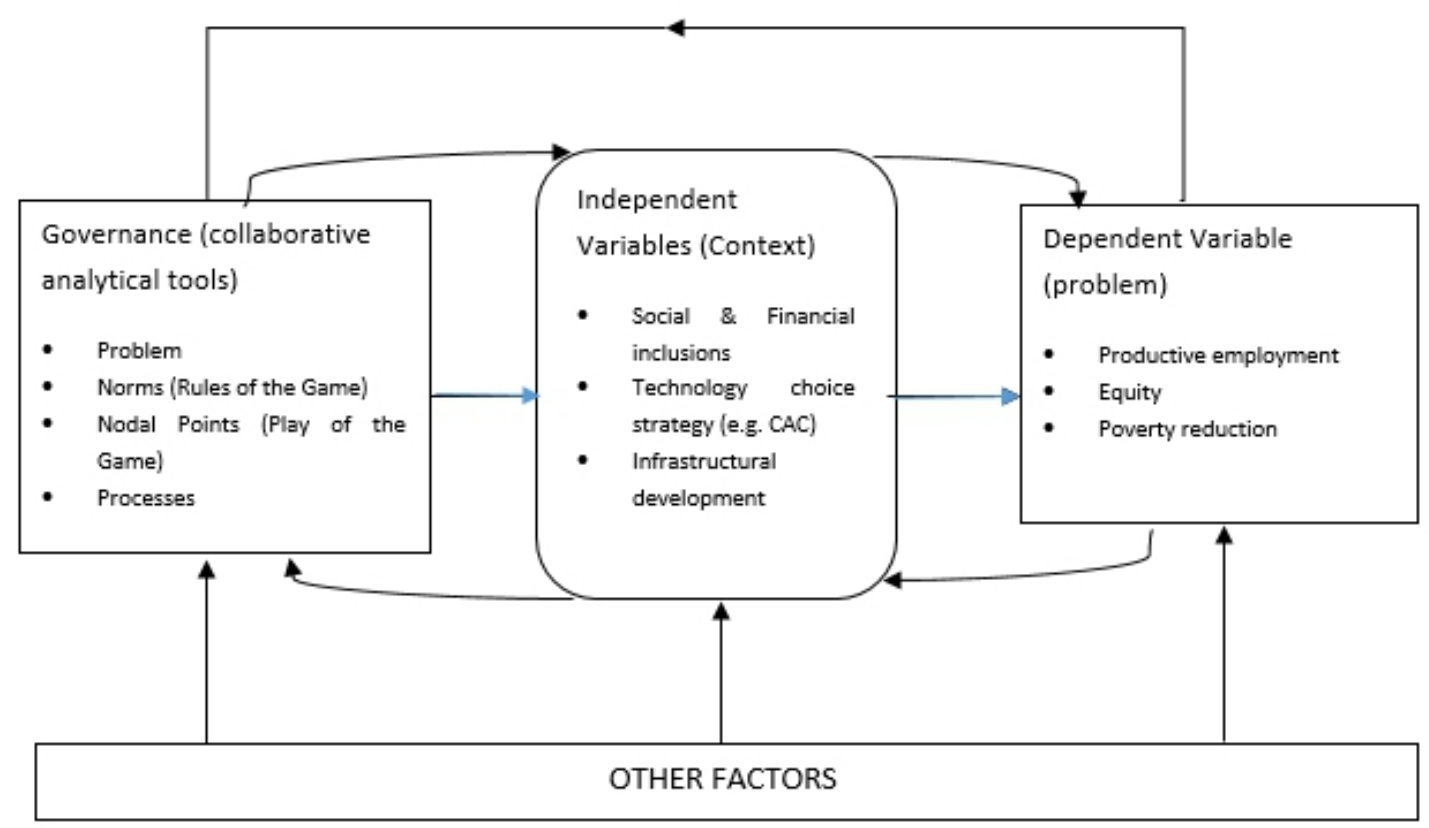

Figure 2.1 Governance Analytical framework: adapted from Hefty (2011)

Given the state's institutional capacity and as an enabler of the production process, adopting appropriate development strategy, Tobin' $\mathrm{s}$ dynamic aggregative production function becomes the benchmark model which traditionally incorporates both structural and institutional development strategies of the modified form of Barro (1991) endogenous growth model, specified as:

$$
y=f(k, g)=(1-T) A k^{1-a} g^{a}
$$

where ' $y$ ' is output growth, ' $k$ ' represents the stock of capital both physical $(K)$ and human $(H)$, ' $g$ ' is a vector of the country's institutional capital $(g)$, comprising of governance effectiveness, rule of law or judicial efficiency, democracy, control of corruption, voice and accountability, social and physical infrastructure, etc.), ' $A$ ' refers to technological progress, and ' $t$ ' refers to technology choice index; $t \in(0, \mathrm{~T}), \mathrm{T}>0$ indicates inappropriate development strategy and $\mathrm{T}$ is a point at which institutional quality is deteriorated to such an extent that modeling framework ceases to apply. However with strong institutions, the value of technology is less than zero that is, $\mathrm{T}<0$, but with weak institution the value of $\mathrm{T}$ is positive. We assume a direct influence of institutional governance effectiveness on financial inclusion and inclusive growth, if its coefficient is positive and statistically significant.

Capturing the effect of institutional quality on inclusive growth of a country-specific combination of resources endowment and inclusive financial 
system to promote a broad-based productive employment growth, the augmented Tobin (1955)'s dynamic aggregative model and Mankiw, Romer and Weil (1992)'s standard macroeconomic growth model is specified in equation (3.2) below:

$$
Y_{t}=(1-T) A_{t} K_{t}^{\alpha_{1}} H_{t}^{\alpha_{2}} L_{t}^{\alpha_{3}} g
$$

where $Y$ is output, $A$ is the efficiency parameter or level of technical progress meant to augment physical capital $(K)$ such as machinery, building and finance; human capital, both skilled $(H)$ and unskilled labour $(L)$, and $\alpha_{1}+\alpha$ $2+\alpha_{3}=1$ exhibiting the standard assumption of constant return to scale. $g$ as earlier defined. Dividing equation (3.3) through by $L$ to have productive employment growth per worker:

$$
y_{t}=(1-T) A_{t} k_{t}^{\alpha_{1}} h_{t}^{\alpha_{2}} g
$$

Institutional effectiveness or quality is implicitly assumed to underlying equations (3.2) and (3.3) such that, institutional complementary capabilities promote appropriate development strategy for productive employment growth as specified in the empirical model of Hall, Sobel, and Crowley (2010):

$$
y_{t}=\alpha_{0}+\delta_{1}(1-T) h_{t}+\beta_{1} h G E F_{t}+\delta_{2}(1-T) k_{t}+\beta_{2} k G E F_{t}+\varepsilon_{t}
$$

where $G E F$ is institutional quality or effectiveness, depicting the culmination average of all the six dimensions of the worldwide governance indicators (WGIs). $\delta_{1}$ and $\delta_{2}$ measure the returns to human and physical capital investments in a country, while $\beta_{1}$ and $\beta_{2}$ indicate the degree of institutional quality attained relative to the ideal standard set as suitable to represent quality of an institutional environment.

The major concern of this present study however, is to explore the interactive links among variables of interest following Hufty (2011) and Djezou (2014) on the empirical influence of quality of institutional governance on inclusive growth as:

$L N R G D P E_{t}=\alpha+\gamma L N R G D P E_{t-1}+\beta_{1} I F I_{t}+\beta_{2} G E F_{t}+\beta_{3} R G D P E * G E F_{t}+\beta_{4} I F I * G E F_{t}+\beta_{5} T C I_{t}+\varepsilon_{t}$

where $R G D P E$ represents a measure for inclusive growth (as proxy for participation and benefit-sharing in the growth process). The annual secondary time series data from 1998 to 2017 were used and mainly sourced from the Central Bank of Nigeria's statistical Bulletin and Annual Report and Statement of Accounts, National Bureau of Statistics' final Accounts, IMF's International Financial Statistics (IFS), World Development Indicators (WDIs) and Worldwide Governance Indicators (WGIs). 


\section{Analysis and Discussion}

Unit Root Tests

The study deployed conventional unit root tests such as Augmented Dickey Fuller (ADF) and Phillips-Perron (PP) techniques to test for the presence of unit root in the series. Table 1 below shows that all the series with the exception of technology choice index (TCI), were found to be nonstationary at level with constant and time trends. This shows that the variables LNRGDPE, IFI, GEFe, RGDPE*GEFe and IFI*GEFe were stationary at first difference. However, none of the variables is integrated at $I(2)$. Therefore, since the data does not contain I(2) series, it lend support to the use of ARDL bounds testing approach to co-integration.

Table 1: Unit Root Tests (Augumented Dickey Fuller (ADF) and Philips-Perron (PP)

\begin{tabular}{|c|c|c|c|c|c|}
\hline \multirow[t]{2}{*}{ Variables/Tests } & t-statistics & $\begin{array}{c}\text { Critical } \\
\text { Value }\end{array}$ & t-statistics & $\begin{array}{c}\text { Critical } \\
\text { Value }\end{array}$ & \multirow[t]{2}{*}{$\begin{array}{c}\text { Order of } \\
\text { Integration }\end{array}$} \\
\hline & \multicolumn{2}{|c|}{ Levels } & \multicolumn{2}{|c|}{ First Difference } & \\
\hline \multicolumn{6}{|l|}{ ADF Test } \\
\hline LNRGDPE & -2.7966 & 3.6736 & $-4.7982 * *$ & -3.6908 & $\mathrm{I}(1)$ \\
\hline IFI & -1.6285 & -3.6908 & $-3.3672 *$ & -3.0522 & $\mathrm{I}(1)$ \\
\hline TCI & $-5.0377 * *$ & -3.8753 & $-5.8491 *$ & -3.1754 & $\mathrm{I}(0)$ \\
\hline GEFe & -2.2221 & -3.6908 & $-4.9752 * *$ & -3.7105 & $\mathrm{I}(1)$ \\
\hline RGDPEGEFe & -2.8151 & -3.6908 & $-4.9904 * *$ & -3.7105 & $\mathrm{I}(1)$ \\
\hline IFIGEFe & -1.6729 & -3.6908 & $-3.8433^{*}$ & -3.0522 & $\mathrm{I}(1)$ \\
\hline \multicolumn{6}{|l|}{ PP Test } \\
\hline LNRGDPE & -2.7966 & -3.6736 & $-4.8848 * *$ & -3.6908 & $\mathrm{I}(1)$ \\
\hline IFI & -1.8030 & -3.6908 & $-3.3766^{*}$ & 3.2978 & $\mathrm{I}(1)$ \\
\hline TCI & -1.4678 & -4.6679 & -2.0946 & -1.9628 & $\mathrm{I}(1)$ \\
\hline GEFe & -2.0175 & -3.6908 & $-4.9752 * *$ & -3.7104 & $\mathrm{I}(1)$ \\
\hline RGDPEGEFe & -2.8151 & -3.6908 & $-5.1956 * *$ & -3.7105 & $\mathrm{I}(1)$ \\
\hline IFIGEFe & -1.6729 & -3.6908 & $-3.9091 *$ & -3.7105 & $\mathrm{I}(1)$ \\
\hline
\end{tabular}

Note: The asterisk (*,**,***) denote the rejection of the unit root hypothesis at the $1 \%, 5 \%$ and $10 \%$ significance levels respectively.

Source: Authors, 2019

Essentially, the null hypothesis for the presence of unit root at levels was rejected for all the variables with the exception of technology choice index (TCI), suggesting that all the series were integrated but after differencing them.

Cointegration Test Result

In order to establish the existence of a long-run equilibrium relationship among the variables, the co-integration test aapplied in this study was the Autoregressive Distributed Lag (ARDL) Bounds testing to co- 
integration procedure proposed by Pesaran et al., (2001). This approach has certain econometric advantages in comparison to other co-integration procedures (Engel \& Granger, 1987; Johansen 1988; Johansen \& Juselius, 1990). One, the approach is applicable regardless of whether the underlying regressors are stationary at $I(0)$ or $I(1)$ or a mixture of both. Moreover, unlike most of these traditional co-integration procedures which are valid for large sample, the approach is not only suitable for small sample size study (Pesaran et al., (2001), but it is of equally far more superior to them all (Narayan, 2005). In addition, it provides unbiased estimates of the long-run model and valid $t$ statistics even when some of the regressors are endogenous (Harris \& Sollis, 2003).

While the lag order of the variables is given in the second column of the Table 2 below, the Bounds test results are reported in the lower segment of the same Table. The calculated F-statistics (15.9350) in the ARDL regressions was found to exceed the upper Bounds critical values of 3.35, 3.79 and 4.68 for significance levels of $10 \%, 5 \%$ and $1 \%$. This implies that the null hypothesis of no co-integration can be rejected at the three conventional significance levels. In other words, there exists a long-run relationship among the series. Thus, inclusive growth indicator (RGDPE), institutional quality index (GEFe), index of financial inclusion (IFI), proxy for the country's resource endowment and development strategy (TCI) and the interacted variables of both institutional quality and real GDP per person employed (RGDPEGEFe) and inclusive finance (IFIGEFe) are co-integrated or comoving in Nigeria over the period of 1998 to 2017.

Table 2: Results of the Bounds Co-integration Test

\begin{tabular}{|c|c|c|c|c|}
\hline \multicolumn{3}{|c|}{ Bounds testing to Cointegration } & \multicolumn{2}{|c|}{$\begin{array}{c}\text { Diagnostic } \\
\text { tests }\end{array}$} \\
\hline Estimated Models & Optimal lag length & $\begin{array}{c}F- \\
\text { statistics }\end{array}$ & $\mathrm{R}^{2}$ & Adj-R ${ }^{2}$ \\
\hline $\begin{array}{l}\text { lnrgdpe }=\mathrm{f}(\mathrm{tci}, \quad \text { ifi } \text { gefe, } \\
\text { rgdpegefe ifigefe) }\end{array}$ & $1,1,1,1,1,1$ & $15.9351 *$ & 0.995 & 0.981 \\
\hline \multicolumn{2}{|c|}{ Significant Level } & \multicolumn{3}{|c|}{ Critical Values } \\
\hline & & & $\begin{array}{l}\text { wer } \\
\text { ands } \\
(0)\end{array}$ & $\begin{array}{c}\text { Upper } \\
\text { bounds } \\
\text { I(1) }\end{array}$ \\
\hline \multicolumn{2}{|c|}{$1 \%$} & \multicolumn{2}{|c|}{3.41} & 4.68 \\
\hline \multicolumn{2}{|c|}{$5 \%$} & \multicolumn{2}{|c|}{2.62} & 3.79 \\
\hline \multicolumn{2}{|c|}{$10 \%$} & \multicolumn{2}{|c|}{2.26} & 3.35 \\
\hline
\end{tabular}

Note: $* * *$ and $* * *$ represent significance at 1,5 and $10 \%$ level respectively.

Source: Authors, (2019)

Since the existence of a long-run relationship among the series was established, the researchers proceeded to estimate the long-run behavioural equilibrium relationship using the vector error correction (VEC) model within 
the ARDL framework. The results of the estimated cointegrated vectors are presented in Table 3 below. The evidence that there exists a long-run relationship among the variables suggests the estimation of the autoregressive distributed lag (ARDL) bounds testing approach to cointegration framework for specifically achieving the stated objective.

Results of Institutional Quality and Inclusive Growth using Autoregressive Distributed Lag Model

The result conforms to the literature that the indicators of financial inclusion and institutional quality factor are positively related to inclusive growth. This suggests that an improved institutional quality would bring about a rise in real GDP per person employed via broad-based financial inclusiveness in Nigeria. This finding also implies that improvement of social infrastructure services such as health and education would generate substantial productive employment capabilities.

Interestingly, the relationship between the inclusive growth variable and the interaction of the financial inclusion with the institutional quality is both positive and statistically significant. Specifically, a $1 \%$ improvement in the quality of institutional governance can stimulate productive employment growth by $42 \%$ in the long run. However, the country's resources endowment indicator (TCI), in contrary to the a-priori expectation revealed positive and weakly statistically significant, indicative of the country's adoption of a comparative advantage defying (CAD) as opposed to the appropriate comparative advantage conforming (CAC) development strategy. Moerover, it was found that the long-run relationship between inclusive growth and the interaction of real GDP per person employed with the institutional variable was negative but statistically significant at $1 \%$ level

Table 3: Results of the Estimated Short-Run ad Long-Run ARDL Model

\begin{tabular}{ccccc}
\hline \hline Short-Run Estimates & & & & \\
\hline \hline Variable & Coefficient & Std. Error & t-Statistic & Prob. \\
\hline \hline D(TCI) & 0.0023 & 0.0006 & 4.1827 & 0.0139 \\
D(IFI) & 0.0077 & 0.0019 & 4.0696 & 0.0152 \\
D(GEFE) & 0.4620 & 0.0845 & 5.4683 & 0.0054 \\
D(RGDPEGEFE) & -1.0103 & 0.0566 & -17.8576 & 0.0001 \\
D(IFIGEFE) & 0.0065 & 0.0017 & 3.8140 & 0.0189 \\
ECM(-1) & -1.3047 & 0.1487 & -8.7725 & 0.0009 \\
\hline \hline
\end{tabular}

Long Run Estimates

\begin{tabular}{crrrr}
\hline \hline Variable & Coefficient & Std. Error & t-Statistic & Prob. \\
\hline \hline TCI & 0.0006 & 0.0004 & 1.7629 & 0.1527
\end{tabular}




\begin{tabular}{cccrr} 
IFI & 0.0079 & 0.0020 & 3.8682 & 0.0180 \\
GEFE & 0.4226 & 0.0395 & 10.7112 & 0.0004 \\
RGDPEGEFE & -0.9470 & 0.0140 & -67.8165 & 0.0000 \\
IFIGEFE & 0.0063 & 0.0018 & 3.5807 & 0.0232 \\
C & -0.6836 & 0.0487 & -14.0237 & 0.0002 \\
\hline \hline$R^{2}=0.99$ & $\overline{R^{2}}=0.98$ & $F-$ stat. $=73.7$ & \\
$* * * * *$ denote significance at 1\%, 5\% and 10\% level respectively &
\end{tabular}

Based on the short-run dynamics, the estimates of the error correction model presented in the Table 3 support the results of the long-run estimates. The error term $(\operatorname{ECM}(-1))$ is negative and highly statistically significant, thus corroborating the results of the cointegration tests of the existence of a stable long-run relationship among the variables. The value of error correction term at -1.31 shows that well over $100 \%$ (131\%) of the previous year's deviation from log-run equilibrium would be restored within a year. Consistent with previous studies on governance and institutional quality (Zhuang, 2010; Chang, 2011; Acemoglu \& Robinson, 2013), real GDP per person employed is positively related to institutional quality. So, as quality of institutional governance becomes better, the broad-based productive capacity of the economy is significantly enhanced with approximately coefficient elasticity of one. The implications of this in the short-run are that efforts to improve institutional governance in Nigeria would have positive impact on the socioeconomic life of the citizens including the poor and the vulnerable group.

In line with a priori expectation, institutional quality was found to be a major determinant of inclusive growth having a positive impact on formal financial services (availability and usage of banking services) during the period investigated. The dominant plausible explanation for these findings could partly be attributed to the transition to democratic governance since 1998. While the interaction of institutional factors with financial impacts positively and statistically significant on inclusive growth, the interaction of governance variable with the real GDP per person employed (RGDPEGEFE was negative, even though strongly statistically significant. Surprisingly, however, it was observed that contrary to the a-priori expectation, the structural variable TCI) positively and statistically significantly impacted on the broad-based productive growth, thus revealing the failure of successive Nigerian governments to adopt appropriate development strategy in converting the nation's huge potentialities into realities of transformative development over the years. 
Stability Test

A diagnostic test for parameter stability was conducted and the result is presented in Table 4 and Figure 2.2 below. All the parameters of the model satisfied the stability condition which further confirms the stationarity properties of the model. Since the autoregressive (AR) process was found to be stable, that is, all the five roots of the characteristic AR polynomial have absolute value less than one and lie inside the unit circle, it implies that the impact of shocks in the variables would diminish over time and the parameter estimates would produce stable dynamics for the inclusive growth model.

The study also estimated the recursive coefficients of the residuals to test for the stability of the long-run estimated parameters together with the short-run movements for the equations. It employed cumulative sum (CUSUM) tests proposed by Borensztein et al. (1998) and earlier used by Pesaran and Pesaran (1999) to test the stability of the long-run coefficients. Figure 2.2 plots the CUSUM statistics for equation (3.5). It can be seen from the Figure that the plot of CUSUM stays within the critical 5 per cent bounds that confirms the long-run relationships among variables and thus shows the stability of coefficients.

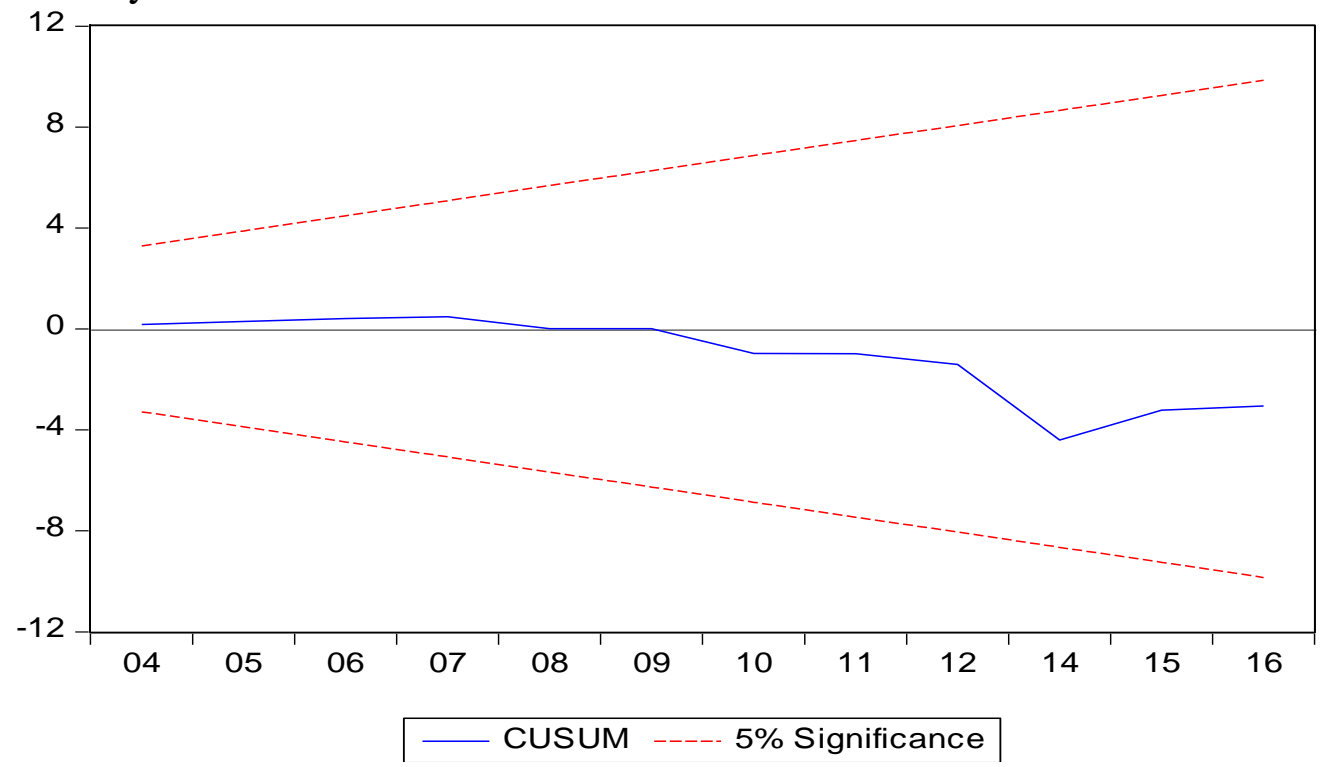

Figure 2.2: Recursive of the Residuals (CUSUM)

The policy implications based on the Lin's growth identification and facilitation framework in resource-rich and labour-abundant developing countries like Nigeria, is that more credible institutional capacities are required to anchor and coordinate an inclusive growth-enhancing process over a longer term. Thus, a high level of inclusiveness becomes the uppermost policy-priority of any growth-oriented institutional leadership, effectively 
tackling those tripartite socio-economic problems earlier on discussed as being the peculiar development challenges of most developing countries. Moreso, the inverse relationship between institutional quality and the preferred development strategy index calls for a consideration by policymakers.

\section{Diagnostic Tests for Residuals}

From the results of the diagnostic tests conducted and reported in appendix B, the Breusch- Godfrey Langrange Multiplier (LM) test did not reject the null hypothesis which stated that 'there is no serial correlation'. This indicated that the error terms were not serially correlated at the $95 \%$ confidence intervals. Similarly, the results of the heteroscedasticity tests (with no cross terms) did not reject the null hypothesis of 'homscedasticity'. This implied that the error terms had constant variance, as the disturbances certified the equal variance assumption. However, the Ramsey RESET test did not reject the null hypothesis of 'no misspecification in all the estimated equations, confirmining that the error correction models were free of specification errors.

Table 4: Diagnostic Tests

\begin{tabular}{|c|c|c|}
\hline Test & F-statistic & Probability \\
\hline$X^{2}$ SERIAL & 1.2580 & 0.4474 \\
\hline$X^{2}$ ARCH & 0.2708 & 0.6099 \\
\hline$X^{2}$ WHITE & 0.9898 & 0.5567 \\
\hline$X^{2}$ RAMSEY & 7.510244 & 0.2699 \\
\hline NORMALITY TEST & & 0.7735 \\
\hline
\end{tabular}

Note: $X^{2}$ Serial is for serial correlation. $X^{2} A R C H$ is for autorgressive conditional heteroscedasticity. $X^{2}$ WHITE is for white heteroscedasticity and $X^{2} R A M S E Y$ for Ramsey Reset test.

These results indicated that the short-run models passed all the relevant diagnostic tests, since there could be no suspicion of multicolinearity among the variables when the functional forms of the models were well specified and the disturbances had equal variances. Moreover, the problem of endogeneity was largely unexpected when the error terms were serially uncorrelated, with the regressors being the lagged values.

In order to achieve the study's objective, the study employed the conventional unit root (Augmented Dickey Fuller and Philips-Perron) to test the stationarity properties of the study's variables. The results showed that all the series except resources endowment indicator (TCI) were non-stationary in their levels, but become stationary after taking the first difference. Hence, we conclude that all series are combination of $I(0)$ and $I(1)$ at the 5 per cent level of significance. This confirmed the relevance and justification for the use of the ARDL cointegration approaches employed.

Looking at the effect of institutional factors on the measures of financial inclusion (IFI) and inclusive growth (RGDPE) in Nigeria during the 
period, an important finding is that the long-run relationship between the real GDP per person employed (RGDPE) and its interaction with the institutional variable (RGDPEGEFE) was negative but statistically significant at $1 \%$ level.

Consistent with the a-priori expectation, the coefficient of the immediate past value of inclusive growth was positively significant at the $5 \%$ level.

On the whole, one of the most important findings that emerged from the regressions discussed above was the strength of the relationship between the composite variable of financial inclusion and institutional quality and inclusive growth. This was not unexpected, since previous studies (King \& Levine, 1993a \& b; Owusu \& Odhambo, 2014; Stiglitz, 2016) on financial development-growth nexus has shown the existence of such a similar dynamic relationship between them. However, the country's resources endowment indicator (TCI) behaved contrarily to the a-priori expectation being positive and weakly statistically significant, revealing the country's wrong adoption of a comparative advantage defying (CAD) as opposed to the relevant comparative advantage conforming (CAC) development strategy. While the interaction of institutional factor with formal banking services was found to positively influenced inclusive growth, the interaction of governance variable with the real GDP per person employed (RGDPEGEFE) was negative, even though strongly statistically significant. Another important finding was that the long-run relationship between the real GDP per person employed (RGDPE) and its interaction with the institutional variable (RGDPEGEFE) is negative but statistically significant at $1 \%$ level. Thus, an inclusive growth, besides being the policy-priority of every purposeful government, its farfetching effects cannot be assessed in an institutional vacuum.

Although, the present study has identified some critical results about the relationship between institutional quality, financial inclusion and inclusive growth, the data employed in this analysis had serious limitations. Owing to lack of appropriate data on financial inclusion (IFI) and the country's preferred development strategy (TCI), the researchers were unable to incorporate many aspects of these variables in the study. For instance, only data on two dimensions (availability and usage) as against the standard three (accessibility, availability and usage) of formal financial services were available for use in this study. Moreover, in the construction of technology choice index, the computation considered only the value-added ratio of labour employment in manufacturing sector to the country's labour force. Meanwhile, the construction of TCI could also as well include value-added in other sectorial activities besides the manufacturing sector. 


\section{Conclusion}

We advanced the fields of both new institution economics (NIE) and new structural economics (NSE) by incorporating technology choices index (CAC or $\mathrm{CAD}$ ), together with the interacted variables of institutional quality with financial inclusion and real GDP per person employed in Nigeria. The study concluded that institutional quality had an overall significant effect on financial inclusion and inclusive growth in Nigeria. Institutional quality is therefore a critical motivator of inclusive growth. Thus, by virtue of its relative capacity to create equitable economic opportunities, the state institution plays a vital role in harnessing both human and natural resources in Nigeria to achieve a broad-based productive employment growth.

It is therefore recommended that institutional improvement beyond the present liberal democratic threshold is much needed to effectively harness the human capital resource base. Specifically, the Nigerian government should adopt labour-intensive development strategy aimed at integrating the active poor households into productive activity for optimal value-chain financegrowth inclusiveness in line with Lin's comparative advantage conforming hypothesis. This approach will largely address the issues of the protracted socio-economic problems of pervasive poverty, huge inequality gaps and jobless growth in the resource-rich and labour-abundant Nigerian economy.

\section{References:}

1. Acemoglu, D. \& J. Robinson, (2013). Why Nations fail: The origin of power, prosperity and poverty. London, Profile Book Ltd.3A Exmouth House Pine Street.

2. Ajayi, S. (2002). "Institutions: The missing links in the growth process?" Presidential address delivered at the $43^{\text {rd }}$ Annual Conference of the Nigerian Economic Society held in Lagos, August, 2002.

3. Anders, O. K. \& Tamayo, O. N. (2015). Measuring inclusive growth experiences: five criteria for productive employment, Paper Presented at UNU-WIDER's Conference, Helsinki, September 20-21.

4. Ayinde, T. \& Yinusa, O. (2016). Financial development and inclusive growth in Nigeria: A threshold analysis, Acta Universitatis Danubius Economica, 12(4), 326-346.

5. Barro, R. J. (1991). Economic growth in a cross-section of countries, Quarterly Journal of Economics, $106(2), 407-443$.

6. Briguglio, L. (2016). Good governance and economic growth: A focus on small island developing economies, Seminar paper presentation at the University of Mauritius, 2016.

7. Bruno, L.; Douarin, E. Korosteleva J. \& Radosevic, S. (2015). Technology choices and growth: new testing new structural 
economics in transition economies, Journal of Economic Policy Reform 18(2), 131- 152.

8. Chang, H. (2011). Institutions and economic development: theory, policy and history, Journal of Institutional Economics, 7(4), 473-498.

9. Durlauf, S. N., Johnson P. A. and Temple, J. R. W. (2005). "Growth econometrics", in Durlauf S.N. and Aghion, P. (eds.), Handbook of economic growth, Elsevier.

10. Engel R. F. \& Granger C. W. (1987). Cointegration and error correction representation: estimation and testing, Econometrica, 55(2), 251-276.

11. Ghatak, S. (2003). Introduction to development economics, 4th edition. Routledge Taylor \& Francis Group, 11 New Fetter Lane, London.

12. Harris R. \& Sollis R. (2003). Applied time series modelling and forecasting, Wiley, West Sussex.

13. Hufty M. (2011). Investigating policy processes: the governance analytical framework (GAF). Research for Sustainable Development: Foundations, Experiences, and Perspectives, University of Bern, 6, 403-424.

14. Johansen S. (1988), 'Statistical analysis of cointegration vectors', Journal of Economic Dynamics and Control, 12(2), 231-254.

15. Johansen S. \& Juselius K. (1990), 'Maximum likelihood estimation and inference on cointegration with applications to the demand for money', Oxford Bulletin of Economics and Statistics, 52(2), 169-210.

16. Kebede, J. \& Takyi, P. (2017). Causality between institutional quality and economic growth: evidence from Sub-Saharan Africa, European Journal of Economic and Financial Research, 2(1), doi 10.5281/zenodo.438146.

17. King, R. \& Levine, R. (1993a). Financial and growth: Schumpeter Might be right, Quarterly Journal of Economics 108, No. 3, 717-737.

18. Kurtz, M. \& Shrank, A. (2007). Growth and governance: models, measures, and mechanisms, The Journal of Politics, 69(2), 538554.

19. La Porta, R., F. Lopez-de-Silanes, A.Shleifer, \& R.Vishny (1998). The quality of government, Journal of Law, Economics, and Organization 15(1) 222-79.

20. Lin, J. Y. (2009). Development strategies for inclusive growth in developing Asia, Paper Presented at Asian Development Bank's Distinguished Speakers Program, 11 October, Manila, Philippines. 
21. Mankiw, N. Romer, G. \& Weil, D. (1992). A contribution to the empirics of economic growth,

Economics, 107(5), 407-437.

Quarterly Journal of

22. Martinez, M. \& M. Mlachila (2013). The quality of the recent high growth episodes in Sub- Saharan Africa, International monetary fund working paper, 13/53, African department.

23. Nawaz, S., Iqbal, N. \& Khan, M. (2014). The impact of institutional quality on economic growth: panel evidence, The Pakistan Development Review 53(1), 15-31.

24. Onwusu, E. \& Odhiambo, M. (2014). Financial liberalisation and economic growth in Nigeria: an ARDL- bounds testing approach, Journal of Economic Policy Reform, 17(2), 164-177, http://dx.doi.org/10.1080/17487870.2013.787803

25. Ozughalu,U. \& Ogwumike, F. (2015). Inclusive growth and poverty reduction in Nigeria, Bullion Publication of the Central Bank of Nigeria (CBN), 39(4), 15-27.

26. Peet, R. \& Elaine, H. (2009). Theories of development: contentions, arguments, alternatives, The Guilford Press, New York, $2^{\text {nd }}$ edition, 165- 270.

27. Pesaran M. H. \& Shin Y. (1999), An autoregressive distributed-led modelling approach to cointegration analysis, Cambridge University Press, Cambridge.

28. Pesaran M. H. \& Shin Y., Smith R. J. (2001), 'Bounds testing approaches to the analysis of level relationships', Journal of Applied Econometrics, 16(3), 289-326.

29. Phillips, P.C. and P. Perron, 1988. Testing for a unit root in a time series regression. Biometrika, 75(2): 335-346.

30. Rodrik, D. (2008). One Economics, many recipes: globalization, institutions, and economic growth, Princeton, Princeton University Press.

31. Sachs, I. (2005). From poverty trap to inclusive development in less developed countries, Economic and Political Weekly, 39(18), 1802- 1811.

32. Saez, L. (2013). Methods in governance research: a review of research approaches, effective states and inclusive development research (ESID) Working Paper, No. 17. University of Manchester, United Kingdom.

33. Sarma, M. \& Pais, J. (2008). Financial inclusion and development, Journal of International Development, 23, 613-628.

34. Siddique, A. (2016). Comparative advantage defying development strategy and cross-country poverty incidence, Journal of Economic Development 41(4), 45-78. 
35. Stiglitz, J. E. (2016). An agenda for sustainable and inclusive growth for emerging markets, The Journal of Policy Modeling, http:/dx.doi.org/10.1016/j.jpolmod. 2016. 1-25.

36. Tobin, J. (1955). Money and economic growth, Econometrica October 1965, 671-684.

37. World Economic Forum (2015). The inclusive growth and development Report. World Economic Forum, 2015, Geneva.

38. Zhuang, J. de Dios, E. \& Lagman-Martin, A. (2010). Governance and institutional quality and the links with economic growth and income inequality: with special reference to developing Asia, ADB Economics Working Paper Series, No. 193/2010. 